\title{
The value of the organic cement matrix in the identification of the shells of fossil testate amoebae
}

\author{
COLIN G. OGDEN' \& ROBERT L. ELLISON ${ }^{2}$ \\ ${ }^{1}$ Department of Zoology, British Museum (Natural History), \\ Cromwell Road, London SW7 5BD, England. \\ ${ }^{2}$ Department of Environmental Sciences, University of Virginia, \\ Charlottesville, Virginia 22903, U.S.A.
}

\begin{abstract}
Shells of fossil testate amoebae isolated from lake sediments in England and Canada have organic cement matrices similar to those possessed by Recent specimens. The surface patterns of individual building units can be useful taxonomic features for confirming the identification of the many species of Difflugiidae found in these environments.
\end{abstract}

\section{INTRODUCTION}

Agglutinate species of testate amoebae are difficult to identify and classify because they have few distinguishing features. Although shape and size of the test are more or less constant within a species, numerous workers have shown that the appearance of the shell is partly a function of the availability and nature of the extraneous material used in test construction. In some species the shell may be significantly modified by the excessive incorporation of particles like pennate diatoms, in others certain types of extraneous particles may be preferred, some species choosing flattish grains and others favouring grains with angular facets. Recently, Ogden (1983a, 1983b, 1984) has shown that in species of the 'Pontigulasia' group the organic cement matrix has a distinct pattern, and that species of Difflugia may be distinguished by the detailed structures of these building units which bind the extraneous material together. Studies of living specimens of most agglutinate species avail little because the nearly opaque shells mask such features as nuclei, contractile vacuoles and other cytoplasmic organelles.

The organic cement matrix is formed into specific building blocks or units which most agglutinate forms of testate amoebae use in constructing a complete casing with a single aperture and with a surface remarkably clean of adventitious debris. Packing of these building units into depressions or cavities, for example between mineral grains, appears to be at random, and the number of building units depends on the number needed to stabilise a particular structure rather than that needed to ensure a smooth inner surface. The build up of these structural units at the interface of adjacent mineral grains in the shell of the agglutinate species Centropyxis discoides Penard, 1890, as described by Ogden (1988a), shows that these units can either be packed between grains or arranged together to form a more or less continuous, smooth sheet. The ability of these units to bind not only to mineral grains but also to each other guarantees that no gaps are left in the structure owing to a lack of material, and contributes to the continuity and strength of the shell matrix.

Netzel $(1976,1977)$ has show that these building units are fabricated in the cell prior to division, being produced in numbers sufficient to construct a shell with the dimensions of the parent even though no extraneous grains were available. Such conclusions have been gained from cultures of Centropyxis and Difflugia grown in the absence of mineral grains (Netzel, 1977; Ogden, 1988a, 1988b). Sections through the organic cement matrix in newly constructed shells show that the basic structural units are hollow squares or rectangles with walls that are thin, but of equal thickness. In species of Centropyxis many of the walls of these units are smooth and featureless, whereas in some members of the Difflugiidae one wall, commonly the outer facing, may have pores or a network of pores. In the difflugiids, wall thickness varies and some of the building units appear to be circular rather than quadrangular. Aggregates of these units are not uncommon in those species of Difflugia that use angular particles in their shells and consequently have a shell surface that is irregular. On the other hand, these aggregates are uncommon in species which use small or flattish particles and consequently, have a smooth-surfaced shell. Structural detail of these building units may have important architectural implications. It may be easier to manipulate such strong yet lightweight units and if each unit carried its own building cement to be released through the pores during construction the unit would fulfil two roles. The latter interpretation has been postulated by Netzel (1977) for Netzelia oviformis (Cash, 1909) and by Harrison et al. (1981) for Lesquereusia spiralis (Ehrenberg, 1840). Pores on the faces 
of some building units may also allow transfer of inorganic chemical constituents from the environment to deposition sites on the inside of the building unit. It is well documented for species like this that the colour of the shell is darkened and the thickness increased by the deposition of complexes of iron and manganese that occur with ageing. However, inasmuch as similar deposition takes place within the compact units produced by Arcella and Centropyxis, the need for pores in the Difflugiidae would seem unnecessary.

Identification of fossil species of testate amoebae from cores of Quaternary sediment must be based on features of the shell, and a guide to the identification of common species using these morphological characters has recently been prepared (Ellison \& Ogden, 1987). Agglutinate species of Centropyxis, Cyclopyxis and Difflugia are most abundant in such cores, but Nebela and Heleopera may also be present. The smaller, siliceous species such as those belonging to the family Euglyphidae generally are absent as complete shells, but may be represented by single shell plates. A recent study by Douglas \& Smol (1987) suggests that these plates, too, may be useful as palaeoindicators in stratigraphic studies. The present report examines the structural details of the surface of fossil shells, compares these features with those of Recent specimens, and verifies the usefulness of studying organic cement in order to confirm taxonomic identifications made microscopically.

\section{MATERIALS AND METHODS}

Samples included in this study came from two sites: Lake Erie, Canada and Ullswater in the English Lake District. The Canadian sample was left at the British Museum by Dr. F. S. Medioli, details of collection and preparation were given in Medioli \& Scott (1983). The Ullswater sample consisted of two fractions, one from $10 \mathrm{~cm}$ below the sediment surface, the other from $196 \mathrm{~cm}$; stratigraphic details for this core (No. 79-2) were given in Haworth \& Allen (1984). These latter specimens were soaked in mild detergent to disaggregate the clay and free the organic debris, and then sieved through screens with mesh sizes of 44 and $60 \mu \mathrm{m}$.

\section{RESULTS}

Six pyriform species of Difflugia, namely bryophila, claviformis, cylindrus, gassowski, parva and viscidula, were selected from the Canadian sample to consider the taxonomic value of the organic cement matrix. Detailed structures are not well preserved in the Ullswater specimens, but wherever possible a comparison between both fossil samples has been included.

Recognition of species using the optical microscope is confirmed by specific differences in the matrixes of organic cement. At the optical level the six species are distinguished by size and shape:

A. small species - less than $130 \mu \mathrm{m}$

1. D. bryophila Penard, 1902 tapers uniformly from one end to the other, in addition the test is composed of coarse, angular grains (PI. 1, fig. 1).

2. D. gassowski Ogden, 1983 has a tubular neck extending for about one-third to half the body length succeeded by an aboral bulb (PI. 1, fig. 2).

B. large species - generally much longer than $130 \mu \mathrm{m}$

1. D. parva Thomas, 1954 has a distinct cylindrical neck followed by a swollen, rounded aboral extremity (Pl. 1, fig. 3).

2. D. cylindrus Thomas, 1953 has a thicker neck and a 'pear-shaped', pyriform appearance (PI. 2, fig. 1).

3. D. claviformis Penard, 1899 is gradually shaped from a cylindrical neck to a swollen posterior third, and then to a pronounced aboral horn (Pl. 2, fig. 3).

4. D. viscidula Penard, 1902 has a regular, almost ovoid, shape that tapers aborally (PI. 2, fig. 2).

Detailed structure of the cement matrix shows differences between $D$. bryophila and $D$. gassowski, the unit wall of the former being thicker and having a finely meshed framework. The Ullswater specimen is most typical, with the outer mesh absent and a central spine projecting from the thin inner mesh (Pl. 1, fig. 7) The 'doughnut ring' shape of one Canadian specimen

\section{Explanation of Plate 1}

Figs. 1-3. Lateral vies of Difflugia bryophila (Fig. 1); D. gassowski (Fig. 2) and D. parva (Fig. 3) to illustrate their respective shapes (scale bars $=50 \mu \mathrm{m}$ ).

Figs. 4-6. Detail of the organic cement matrix of D. bryophila (Fig. 4); D. gassowski (Fig. 5) and D. parva (Fig. 6). (scale bars $=1 \mu \mathrm{m}$ )

Fig. 7. Detail of eroded building units comprising the organic cement matrix of $D$. bryophila, note the central core. (scale bar $=0.5 \mu \mathrm{m}$ ).

Figs. 8 and 9. Oral views of $D$. parva showing fusion of building units around the aperture (scale bars $=5$ and $20 \mu \mathrm{m})$. 

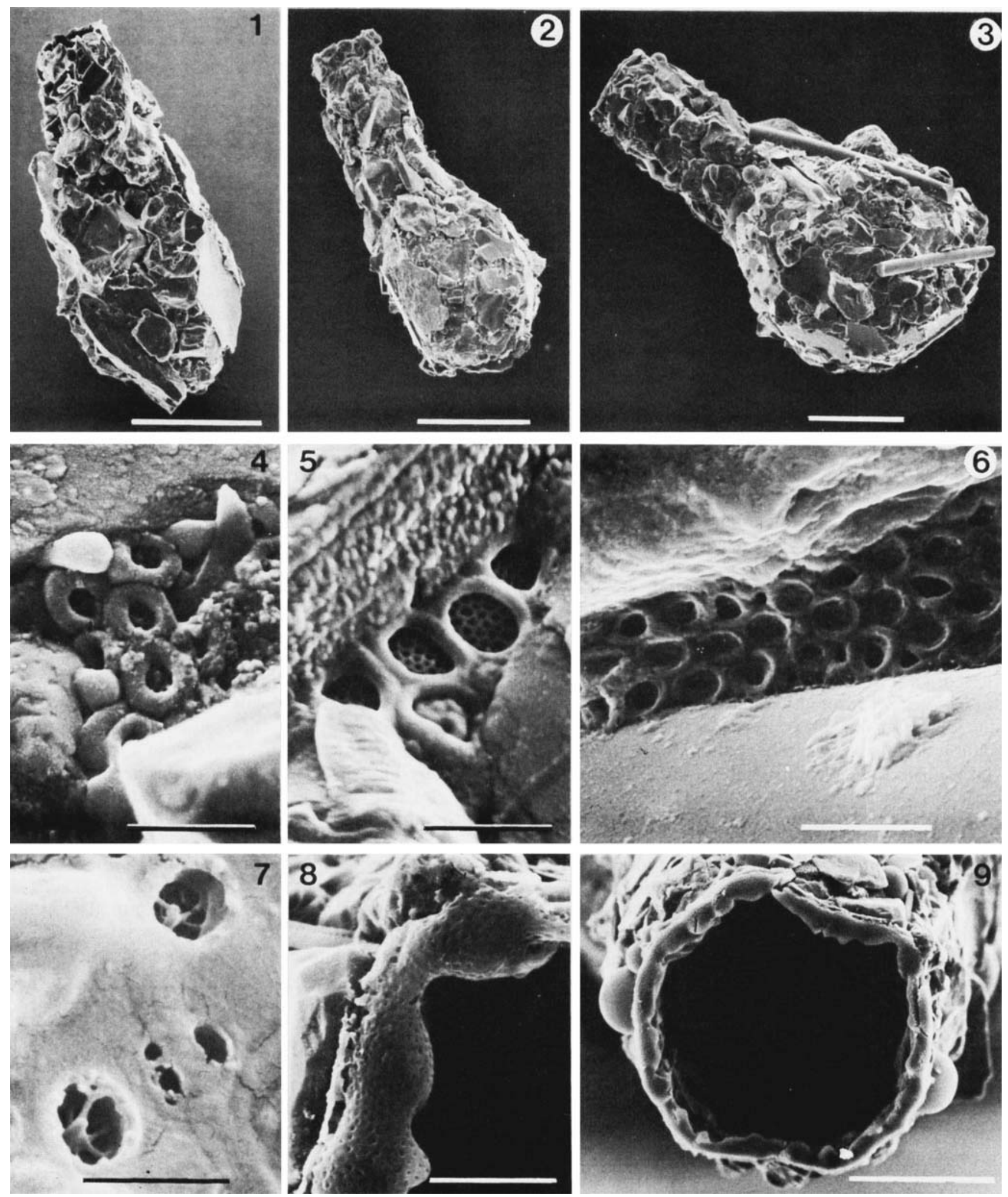
shows the same unit, but in this instance the walls have not fused into an even sheet (PI. 1, fig. 4). In contrast, the units of $D$. gassowski have a larger individual diameter and the framework is a clearly defined mesh (PI. 1, fig. 5). Both of these species compare well with descriptions given of Recent material by Ogden (1983a).

The details of the organic cement matrix in the four larger species also show differences. In $D$. parva the units are small, have an indistinct mesh (Pl. 1, fig. 6) and fuse to form a margin around the apertural rim (PI. 1 , figs. 8 and 9). They are much larger and less regular in D. cylindrus, but again have a complete mesh (PI. 2, fig. 4). The matrix seen in $D$. claviformis is of similar dimensions to that of $D$. parva and has an indistinct inner mesh, broken in much of the present material (PI. 2 , fig. 6). The cement units of $D$. viscidula are distinct in comparison with the other five, being disc-like with a shallow central depression and two median pores or holes (Pl. 2, fig. 5). Again this is in good agreement with the description of Recent specimens (Ogden, 1983a).

The distribution of these cement units on the surface of the shell may prove to be a significant feature. For example, in the two smaller species the units are not seen in most specimens and compose only small areas, whilst in the four larger species the units may contribute significantly to the general shell matrix and cover large areas of the surface.

The organic cement units of Zivkovicia (Pontigulasia) compressa (Carter, 1864) have been well preserved in the Ullswater specimens and show the fusion of these regular units into a typical sheet of binding material (PI. 2 , fig. 8). Detailed examination suggests the presence of a further inner structure behind the outer mesh. This inner structure has been more clearly identified in Recent material where the outer mesh has been broken, as a separate, circular, perforated disc (PI. 2, fig. 9). This inner, perforated disc has also been identified in Recent specimens of Pontigulasia rhumbleri Hopkinson, 1919 and Lagenodifflugia bryophila (Penard, 1902), two other species belonging to the
'Pontigulasia' group (see Ogden, 1987). The significant taxonomic feature of Zivkovicia is a strong internal diaphragm, clearly seen here (PI. 2, fig. 7) in a broken specimen from Ullswater.

Although they are more delicate to handle as washed and air-dried individuals often collapse and distort during preparation, the empty shells of Nebela carinata (Archer, 1867) from the Ullswater sample appear to be identical with Recent examples. The organic cement matrix in these specimens cannot usually be seen as a surface feature, but differences such as collapsing suggest that the cement may have been altered, therefore a comparison of sectioned shells was undertaken. Both fossil and Recent specimens, the latter collected in 1986 from Ullswater, were fixed in buffered glutaraldehyde, postfixed in osmium tetroxide, dehydrated and then embedded in Epon resin. Comparative sections show that the structure of the cement, here seen as a thin, continuous sheet holding siliceous shell plates in position, is similar in both samples. Nevertheless, the siliceous structure of shell plates is different with the outer $0.2 \mu \mathrm{m}$ coating of each plate, in fossil specimens, being seen as a less amorphous layer (Pl. 3, figs. 1 and 2), whilst the remainder of the inner core showed the usual fracture patterns (Pl. 3, fig. 1) of impregnated siliceous shell plates (see Hedley \& Ogden, 1973, 1974). Recent specimens did not share this feature, but shattered as expected.

\section{DISCUSSION}

The micropalaeontologist studying testate amoebae is confronted with a not uncommon taxonomical dilemma. Features such as cytoplasmic characteristics used by biologists for identification and classification are not preserved in fossil specimens. Consequently, taxonomists working with living material will, in their search for persistent diagnostic features, naturally recognise more species than the taxonomist working with fossil material can. Similarly, some taxonomic methods may be impractical for the micropalaeontologist studying communities of these organisms with the aid of optical microscopy. It may be necessary to refer

\section{Explanation of Plate 2}

Figs. 1-3. Lateral views of D. cylindrus (Fig. 1), D. viscidula (Fig. 2) and D. claviformis (Fig. 3). (scale bars $=100 \mu \mathrm{m}$ ).

Figs. 4-6. Detail of the organic cement matrix of D. cylindrus (Fig. 4), D. viscidula (Fig. 5) and D. claviformis (Fig. 6). (scale bars $=1 \mu \mathrm{m})$.

Fig. 7. Broken section of Zivkovicia compressa, from Ullswater, with the inner diaphragm complete. (scale bar $=50 \mu \mathrm{m})$.

Fig. 8. Detail of the organic cement matrix from another Ullswater specimen of $Z$. compressa showing partially damaged outer pattern and inner disc (arrows). (scale bar $=0.5 \mu \mathrm{m}$ ).

Fig. 9. Inner disc in a Recent specimen of $Z$. compressa. (scale bar $=0.5 \mu \mathrm{m}$ ). 

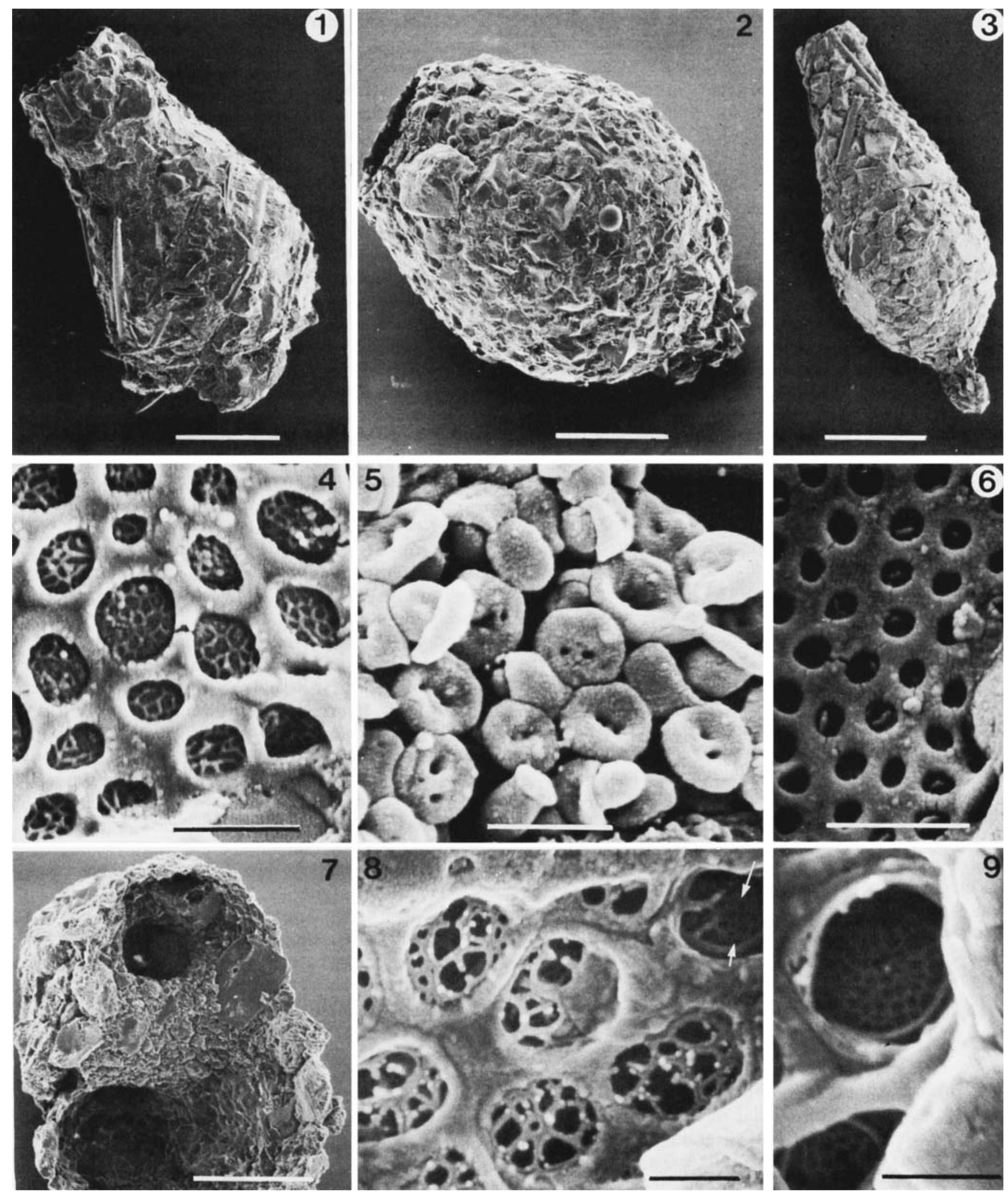
to 'species complexes' in those instances when the micropalaeontologist is not able, on the basis of gross morphology alone, readily to distinguish species recognised by the biologist. We believe that the major taxonomic changes proposed for the Rhizopoda by Medioli \& Scott (1983), Medioli et al. (1987) \& Patterson et al. (1985), in their studies of Recent and fossil material from Lake Erie, Canada, are premature. Their work is limited by its emphasis on descriptions by earlier workers. However, studies utilising highmagnification electron microscopy, reveal features that can be diagnostic in testate amoebae taxonomy. In particular, we are convinced that examination of the organic component of the shell matrix confirms the validity of many species, and we have attempted to demonstrate this for the several species described in this present study.

The two smaller species, $D$. bryophila and $D$. gassowski, were considered by Medioli and Scott (1983) to be synonyms of $D$. oblonga Ehrenberg, 1832. However, the descriptions given here agree with those for Recent specimens (Ogden, 1983a), and the three species are considered to be distinct both by their architectural morphology and in the nature of the organic cement units. Our sample from Lake Erie also contained numerous specimens of $D$. viscidula with cement units typical of Recent specimens of that species (Ogden, 1983a). In not identifying that species, Medioli \& Scott (1983) may have considered similar specimens to be within their description of $D$. urceolata for which they figured some specimens without the distinctive collar. Our specimens of $D$. urceolata all have a well defined, incurved collar, and whilst agreeing with Medioli \& Scott that the collar does vary, it is neverthleless, a distinct feature and the variation appears to be limited to the length or extent of the overhanging rim of the collar.

Furthermore, we believe that their (Medioli \& Scott, 1983) inclusion of six species of Difflugia as synonyms under the specific name $D$. protaeiformis Lamark, 1816, while perhaps expedient, is not correct. These species, $D$. acuminata Ehrenberg, $1838, D$. acutissima Deflandre, 1931, D. claviformis Penard, 1899, D. lanceolata, Penard, 1890, D. scalpellum Penard, 1899 and D. smilion Gauthier-Lièvre \& Thomas, 1958, all have well-defined, albeit not always unambiguous, shapes. Of these species, three namely $D$. acuminata, $D$. scalpellum and $D$. smilion have surfaces that are rough and composed of angular mineral particles, the others are constructed of flattish grains to produce a smooth surface and a regular outline. The incorporation of mineral grains of certain shapes and sizes could be accidental and represent simply a selection of what is available. However, the co-occurence of species some of which have rough and some smooth shells suggests that these species are selective. Similarly, in most soil, freshwater and marine biotopes, where these animals are common, a modest selection of grain shapes and sizes is present, and yet the shell composition and structure within a species is, in most cases, constant. Although these characters should be sufficient for identification of these species at the level of optical microscopy, the recognition of different organic matrices would further support their taxonomic validity.

Concerning the use of the trivial name protaeiformis, it was used by Lamarck (1816), very generally, to include several figures given by Leclerc (1815) in describing the generic name Difflugia. These figures were considered by later workers (Leidy, 1879; Penard, 1902 and Cash \& Hopkinson, 1909) to represent several species, only one of which was an 'acuminate' form, which itself was subsequently identified by them as being a synonym of $D$. acuminata Ehrenberg, 1838. The name was resurrected by Loeblich \& Tappan (1964) who designated it as the type species of Difflugia, based on Leclerc's figures, although the name had not been used since 1880. A thorough investigation into the generic status has been carried out by Merifield (pers. comm.) who argues that the International Code of Zoological Nomenclature (ICZN), Article 74b states that a lectotype figure must represent a syntype specimen. However, as Lamarck's description does not allude to any 'acuminate' form, it seems reasonable to assume that he read an incomplete draft of Leclerc's manuscript, before publication, and that the final draft included the form shown in Leclerc's Fig. 5, this figure was not included in Lamarck's description because it was published later. It follows that its selection by Loeblich \& Tappan as a syntype of $D$. protaeiformis is invalid and, as a consequence, should be rejected as being contrary to Article $74 \mathrm{~b}$. A complete justification of this opinion is in preparation (Merifield, in prep.) for submission to the Commission, in which it is hoped to designate a more correct type species for Difflugia.

The value of the internal diaphragm as a diagnostic feature in Zivkovicia compressa (Carter, 1864) has been argued elsewhere (Ogden, 1983c, 1987), but the permanence of this structure is emphasised here by the inclusion of views of a fractured specimen (Pl. 2, figs. 7 and 8), which came from the Ullswater core at a sediment-depth of $196 \mathrm{~cm}$ and has an estimated age of 2500BP (Haworth \& Allen, 1984). The units of the organic cement matrix are fully intact and directly comparable with Recent specimens. An additional inner disc, revealed by improved microscope resolution, is also noted in both fossil and Recent specimens. This disc appears to be unique to the 'Pontigulasia' group of species, and one can only presume that its function is structural, providing reinforcement for the cement unit.

Although no detectable structural differences were 

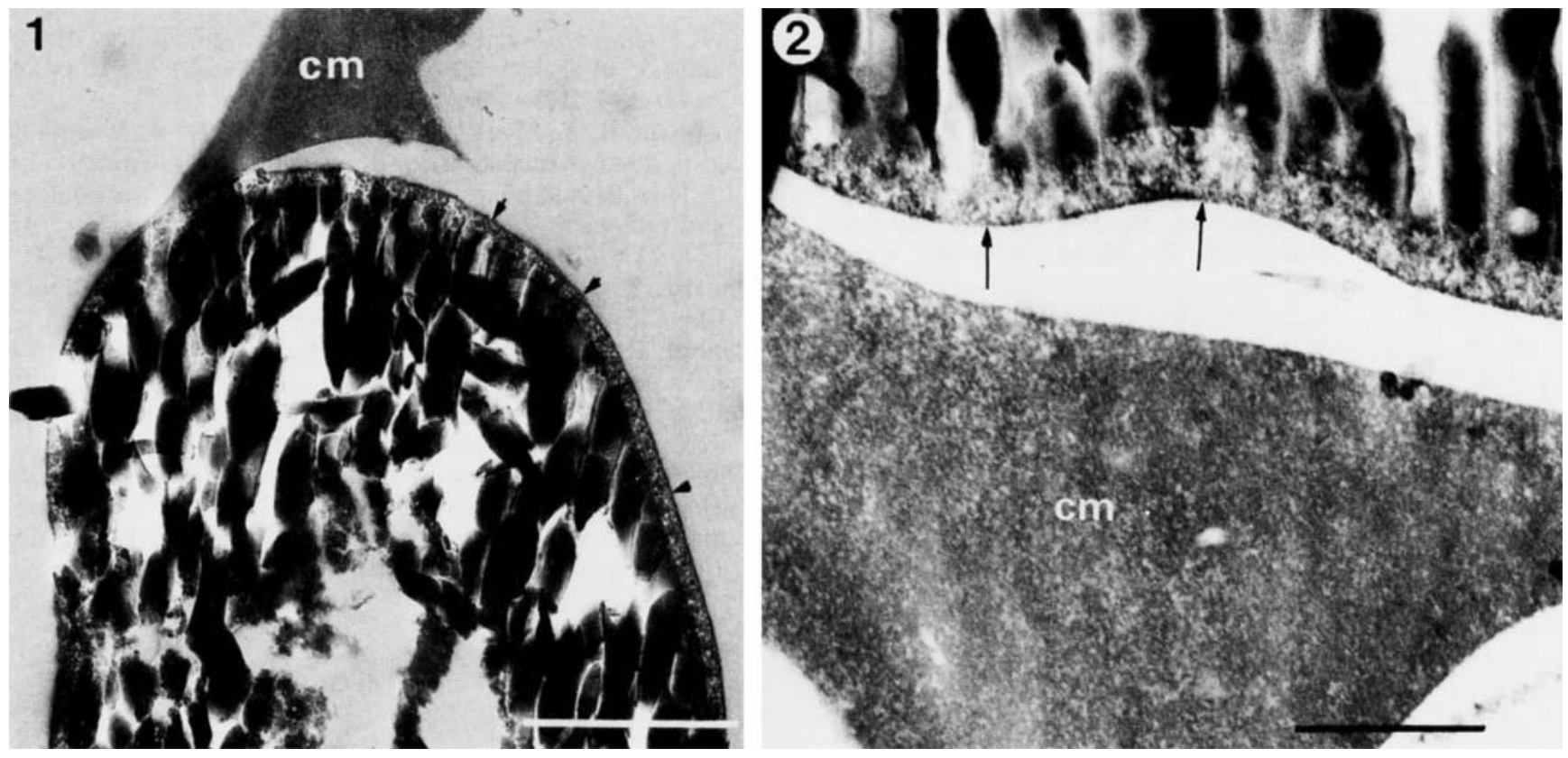

Explanation of Plate 3

Figs. 1 and 2. Sections through the shell wall of Nebela carinata to illustrate the thin, less-amorphous layer surrounding each fractured shell plate (arrows) and the thin layer of organic cement $(\mathrm{cm})$. (scale bars $=1$ and $0.5 \mu \mathrm{m})$.

seen in the organic cement matrix of fossil species of Nebela, the change in the outer surface of the siliceous plates suggests the beginning of shell degeneration. This proposed hypothesis follows the observations of Mann \& Williams (1983), who showed that the external surface layer of siliceous costal strips of a choanoflagellate are actively bound by cations of iron, and they suggested that this elemental layer possibly stablised the surface silica. If a similar layer exists at the surface of the siliceous plates of Nebela, then the loss of elemental iron at this surface may signal the onset of decay.

Species in palaeontology primarily are based on morphology and if the specimens are unaltered, on texture and composition of the shell. Such taxonomy, however, represents an abbreviation of the taxonomy of the biologist. Detailed examination of interstitial cement units with scanning electron microscopy provides convincing evidence for the validity of morphological species.

Manuscript received December 1987

Revised manuscript accepted April 1988

\section{REFERENCES}

Archer, W. 1867. Remarks of freshwater Rhizopoda. Q. $J l$. microsco. Sci., 7, 177-179.

Carter, H. J. 1864. On freshwater Rhizopoda of England and India. Ann. Mag. nat. Hist. (3) 13, 18-39.

Cash, J. \& Hopkinson, J. 1909. The British Freshwater Rhizopoda and Heliozoa v. 2 Rhizopoda, pt. 2, 166 p. The Ray Society, London.

Cash, J., Wailes, G. H. \& Hopkinson, J. 1919. The British Freshwater Rhizopoda and Heliozoa, v. 4 Suppl. to the Rhizopoda, 130 p. The Ray Society, London.

Douglas, M. S. V. \& Smol, J. P. 1987. Siliceous protozoan plates in lake sediments. Hydrobiologia, 72.

Ellison, R. L. \& Ogden, C. G. 1987. A guide to the study and identification of fossil testate amoebae in Quaternary lake sediments. Int. Revue ges. Hydrobiol., 72, 639-652.

Ehrenberg, C. G. 1832. Uber die Entwicklung und Lebensdauer der Infusionsthiere, nebst ferneren Beiträgen zu einer Verleichung ihrer organischen Systeme. Phys. Math. Abh. K. Akad. Wiss., Berlin, 1831, 1-154.Ehrenber, C. G. 1838. Die Infusionsthierchenals vollkommene Organismen. Ein Blick in das tiefere organiche Leben der Natur., 547 p. L. Voss, Leipzig.

Ehrenberg, C. G. 1840. Das grossere Infusorienwerke. Ber. Akad. Wiss., Berlin, 198-219.

Deflandre, G. 1931. Thécamoebiens nouveaux ou peu connus, I. Annals. Protist., 3, 81-95.

Gauthier-Lièvre, L. \& Thomas, R. 1958. Les genres Difflugia, Pentagonia, Maghrebia et Hoogenraadia (Rhizopodes Testacés) en Afrique. Arch. Protistenk., 103, 241-370. 
Harrison, F. W., Dunkelberger, D., Watabe, N. \& Stump, A. B. 1981. Ultrastructure and deposition of silica in rhizopod amoebae. In Simpson, T. L. \& Volcani, B. E. (Eds.), Silicon and siliceous structures in biological systems, 281-294, Springer-Verlag, New York.

Haworth, E. Y. \& Allen, P. V. 1984. Temporary changes in the composition of a postglacial diatom profile from Ullswater. In: Proceedings of 7 th International Diatom Symposium 1982 (Ed.), D. G. Mann, 431-442, Otto Koeltz, Koenigstein.

Hedley, R. H. \& Ogden, C. G. 1972. Biology and fine structure of Euglypha rotunda (Testacea: Protozoa). Bull. Br. Mus. nat. Hist. (Zool.), 25, 119-137.

Hedley, R. H. \& Ogden, C. G. 1974. Observations on Tinema lineare Penard (Testacea: Protozoa). Bull. Br. Mus. nat. Hist. (Zool.), 26, 187-199.

Lamarck, J. B. M. 1916. Histoire naturelle des Animaux sans Vertèbres. Paris.

Leclerc, M. 1815. Note sur Difflugie, nouveau genre de Polype amorphe. Mem. Mus. Hist. nat., Paris, 2, 474-478.

Leidy, J. 1879. Freshwater Rhizopods of North America. U.S. Geological Survey of the Territories 12, $324 \mathrm{pp}$. Washington, D.C.

Loeblich, A. R. \& Tappan, H. 1964. Thecamoebians. In Treatise on Invertebrate Paleontology. (Ed.), Moore, R. C., Pt. C Protists 2, C16-C54. Geol. Soc. America, Univ. Kansas Press, Lawrence, Kansas.

Mann, S. \& Williams, R. J. P. 1983. High resolution electron microscopy studies of the silica lorica in the choanoflagellate Stephaoeca diplocostata, Ellis. In Westbroek, P. \& Dejong, E. W. (Eds.). Biomineralisation and Biological metal accumulation, 407-412. D. Reidel, Dodrecht, Holland.

Medioli, F. S. \& Scott, D. B. 1983. Holocene Arcellacea (Thecamoebians) from Eastern Canada. Cushman Found. Foram. Res. Publ., 21, 63 p.

Medioli, F. S., Scott, D. B. \& Abbott, B. H. 1987. A case of protozoan intraclonal variability: taxonomic implacations. J. Foramin. Res., 17, 28-47.

Netzel, H. 1976. Die Ultrastruktur der Schale von Difflugia oviformis (Rhizopoda, Testacea). Arch. Protistenk., 118, 321-339.

Netzel, H. 1977. Die Bildung des Gehauses bei Difflugia oviformis (Rhizopoda, Testacea). Arch. Protistenk., 119, $1-30$.

Ogden, C. G. 1983a. Observations on the systematics of the genus Difflugia in Britain (Rhizopoda: Protozoa). Bull. Brit. Mus. nat. Hist. (Zool.), 44, 1-73.

Ogden, C. G. 1983b. Morphological studies on some Difflugiidae from Yugoslavia (Rhizopoda: Protozoa). Bull. Brit. Mus. nat. Hist. (Zool.), 44, 341-375.

Ogden, C. G. 1983c. The significance of the inner dividing wall in Pontigulasia Rhumbler and Zivkovicia gen. nov. (Protozoa: Rhizopoda). Protistologica, 19, 215-229.

Ogden, C. G. 1984. Notes on testate amoebae (Protozoa: Rhizopoda) from Lake Vlasina, Yugoslavia. Bull. Brit. Mus. nat. Hist. (Zool.), 47, 241-263.

Ogden, C. G. 1987. The taxonomic status of the genera Pontigulasia, Lagenodifflugia and Zivkovicia (Rhizopoda: Difflugiidae). Bull. Brit. Mus. nat. Hist. (Zool.), 52, 13-17.

Ogden, C. G. 1988a. The role of the organic matrix in the construction of the agglutinate shell of Centropyxis discoides (Rhizopoda: Protzoa). J. nat. Hist., 22, 137-148.
Ogden, C. G. 1988b. Morphology of the organic shell matrix of Difflugia in culture, including modifications by the addition of agglutinate particles (Rhizopoda). Arch. Protistenk., 136, 365-376.

Patterson, R. T., MacKinnon, K. D., Scott, D. B. \& Medioli, F. S. 1985. Arcellaceans ("thecamoebians") in small lakes of New Brunswick and Nova Scotia: modern distributions and Holocene stratigraphic changes. J. foramin. Res. , 15 , 114-137.

Penard, E. 1890. Études sur les Rhizopodes d'eau douce. Mem. Soc. Phys. Hist. nat.. Genève, 31, 1-230.

Penard, E. 1899. Les Rhizopodes de faune profonde dans le lac Léman. Revue suisse Zool. , 7, 1-142.

Penard, E. 1902. Faune Rhizopodique du bassin du Léman. $714 \mathrm{pp}$, Genève.

Thomas, R. 1953. Sur deux formes critiques due genre Difflugia Leclerc. Bull. Soc. Zool. Fr., 78, 132-136.

Thomas, R. 1954. Thécamoebians de la région Bordelaise. Bull. Soc. Hist. nat. toulouse, 89, 245-264. 